\title{
Preferential Binding of Anti-Neutrophil Cytoplasmic Antibodies to an Unexpected Epitope of a Chimeric Proteinase 3 Mutant
}

Marta Casal Moura ${ }^{a},{ }^{*}$, Gwen E. Thompson a, ${ }^{*}$, Darlene A. Nelson ${ }^{\mathrm{a}}$, Lynn A. Fussnera ${ }^{\mathrm{a}}$, Amber M. Hummel $^{\mathrm{a}}$, Dieter E. Jenne ${ }^{\mathrm{b}}$, Daniel Emerling ${ }^{\mathrm{c}}$, Wayne Volkmuth ${ }^{\mathrm{c}}$, Fernando C. Fervenza ${ }^{\mathrm{a}}$, Cees G.M. Kallenberg', Carol A. Langford ${ }^{\text {e }}$, Joseph W. McCune ${ }^{f}$, Peter A. Merkelg, Paul A. Monach ${ }^{\mathrm{h}}$, Philip Seo ${ }^{i}$, Robert F. Spiera ${ }^{j}$, E. William St. Clairk, Steven R. Ytterberga ${ }^{\text {a }}$, John H. Stone', William H. Robinson ${ }^{\mathrm{m}}$, Yuan-Ping Pang ${ }^{\mathrm{a}}$, Ulrich Specks ${ }^{\mathrm{a}, \dagger}$ for the WGET and RAVE-ITN Research Groups

\section{Affiliations}

${ }^{a}$ Mayo Clinic and Foundation, Rochester, MN

${ }^{b}$ Helmholtz Center, Munich, Germany

cAtreca, Inc., Redwood City, CA

dUniversity of Groningen, Groningen, the Netherlands

${ }^{e}$ Cleveland Clinic Foundation, Cleveland, $\mathrm{OH}$

fUniversity of Michigan, Ann Arbor, MI

gUniversity of Pennsylvania, Philadelphia, PA

hoston University Medical Center, Boston, MA

iJohns Hopkins University, Baltimore, MD

jHospital for Special Surgery, New York, NY

kDuke University, Durham, NC

${ }^{1}$ Massachusetts General Hospital, Boston, MA

mStanford University, Palo Alto, CA

*MCM and GET contributed equally to this work.

†Corresponding author: Ulrich Specks MD, Stabile 8-56, Mayo Clinic, 200 First Street SW, Rochester, MN 55905, USA; E-mail: specks.ulrich@mayo.edu

Keywords: Autoimmune disease; granulomatosis with polyangiitis; anti-neutrophil cytoplasmic antibody; proteinase 3; epitope mapping; allosteric effect.

\section{Word Count: 3857}


[Type text]

\section{Abstract}

Proteinase 3 (PR3) is the major antigen for anti-neutrophil cytoplasmic antibodies (ANCAs) in the systemic autoimmune vasculitis, granulomatosis with polyangiitis (GPA). PR3-targeting ANCAs (PR3-ANCAs) recognize different epitopes on PR3 and are thought to be pathogenic for the development of the necrotizing vasculitis. To identify epitopes recognized by PR3-ANCAs, we pursued a strategy based on human-murine chimeric PR3 mutants. Interestingly, rather than observing reduced binding of PR3-ANCAs to Epitope 5 on a PR3 mutant (iHm5-Val ${ }^{103}$ ) with chimeric mutations in Epitope 5, we found substantially increased binding of the majority of PR3-ANCAs to iHm5-Val ${ }^{103}$ compared with the PR3 mutant (iPR3-Val ${ }^{103}$ ) clinically used to detect PR3-ANCAs. More interestingly, using iHm5-Val ${ }^{103}$ we identified a monoclonal antibody (moANCA518) from a patient with GPA that bound selectively to iHm5-Val ${ }^{103}$. Inhibition experiments using epitope-specific monoclonal antibodies and their antigen-binding fragments mapped the binding sites of moANCA518 and PR3-ANCAs (from patients displaying preferential binding to $\mathrm{iHm} 5-\mathrm{Val}^{103}$ over iPR3-Val ${ }^{103}$ ) to Epitope 3 on $\mathrm{iHm} 5-\mathrm{Val}{ }^{103}$, a mutationfree epitope located far from the mutation sites in Epitope 5. These results demonstrate that the selective binding of moANCA518 (and likely the preferential binding of PR3-ANCAs from patients) to $\mathrm{iHm} 5-\mathrm{Val}^{103}$ is conferred by increased antigenicity of Epitope 3 on $\mathrm{iHm} 5-\mathrm{Val}{ }^{103}$ caused by distal mutations, indicating that PR3-ANCAs bind to epitopes of a folded antigen conducive to allosteric effects of mutations - a previously unrecognized characteristic with implications for studying antibody-mediated autoimmune diseases and novel treatment approaches.

\section{Abstract word count: 232}


[Type text]

\section{Introduction}

Anti-neutrophil cytoplasmic autoantibody (ANCA)-associated vasculitis (AAV) comprises a group of systemic small-vessel vasculitis syndromes including granulomatosis with polyangiitis (GPA), microscopic polyangiitis (MPA), and eosinophilic granulomatosis with polyangiitis (EGPA) [1]. The two major target antigens for the ANCAs in vasculitis are proteinase 3 (PR3) and myeloperoxidase (MPO) [2-4]. Testing for the presence of ANCAs has become indispensable in the evaluation of patients suspected of having AAV [5]. Patients with PR3-targeting ANCAs (PR3-ANCAs) are at a much higher risk for relapses than patients with myeloperoxidase-targeting ANCAs (MPO-ANCAs). In addition, PR3-ANCA positivity and rising titers following treatment portend relapses, particularly for patients with renal disease and other disease manifestations of capillaritis [6-8]. The binding of PR3-ANCAs to PR3 has many well-documented pro-inflammatory effects, and PR3-ANCAs are thought to play a pathogenic role for the development of necrotizing vasculitis [9-11].

The oligoclonal PR3-ANCAs from patients with GPA are known to bind to different epitopes of the folded PR3 antigen, whereas denatured PR3 or improperly folded recombinant PR3 generated in non-mammalian expression systems do not bind PR3-ANCAs reliably [12-14]. Consistently, studies of continuous epitope mapping of PR3-ANCAs using oligopeptides have generated inconclusive results [15-18].

In this context, we performed instead discontinuous epitope mapping of anti-PR3 monoclonal antibodies (moAbs) and PR3-ANCAs using human-murine chimeric mutants to obtain mechanistic insights into how interactions of PR3 with its environment during inflammation are modified by PR3-ANCAs and potentially targetable by therapeutics [19]. Herein, the iPR3-Val ${ }^{103}$ mutant represents the most prevalent wild-type PR3 polymorphism 
[Type text]

(Val103) and contains the Ser195Ala mutation at the active site (Fig. 1) to avoid potential enzymatic degradation of ANCAs or PR3-capturing moAbs by PR3 in immunoassays or cytotoxicity when PR3 is expressed in the 293 kidney epithelial cells [19-23]. Because it has the same folded conformation of the wild-type mature PR3, iPR3-Val ${ }^{103}$ has been used for two decades as a standard PR3 antigen for sensitive and specific PR3-ANCA detection by immunoassay [7, 21, 24-29].

In our epitope mapping study, we developed a human-murine chimeric mutant of iPR3$\mathrm{Val}^{103}$ (iHm5-Val ${ }^{103}$; formerly referred to as $\mathrm{Hm} 5$ [19]) to investigate the involvement of Epitope 5 on PR3 - an epitope defined by binding of a group of moAbs including MCPR3-7—in the binding of PR3 to neutrophil membranes [19, 30, 31]. Because this mutant has its three hydrophobic/aromatic residues (Ala146, Trp218, and Leu223; Fig. 1) of human PR3 replaced by their murine hydrophilic counterparts (Thr146, Arg218, and Gln223), we expected that the PR3ANCAs would show reduced binding to the mutated epitopes on $\mathrm{iHm} 5-\mathrm{Val}^{103}$ relative to iPR3$\mathrm{Val}^{103}$. Unexpectedly, we found that PR3-ANCAs either have similar binding to both antigens or preferential binding to $\mathrm{iHm} 5-\mathrm{Val}^{103}$.

Informed by this background, we conducted the present study using large well-defined patient cohorts to (i) determine the scope of this preferential binding of PR3-ANCAs to iHm5$\mathrm{Val}^{103}$, (ii) analyze the potential utility of $\mathrm{iHm} 5-\mathrm{Val}^{103}$ as an in vitro antigen for PR3-ANCA detection, and (iii) identify the epitope(s) involved in this substantially enhanced antigenicity of iHm5-Val ${ }^{103}$ for PR3-ANCAs for a better understanding of mechanistic details with relevance to the cause of antibody-mediated autoimmune diseases and the design of potential novel treatment approaches. 
[Type text]

\section{Material and methods}

Reagents were obtained from Sigma (St. Louis, MO) unless specified otherwise. The human epithelial kidney cell line 293 used for the expression of recombinant PR3 mutants was obtained from ATCC (Rockville, MD).

\subsection{Recombinant PR3 mutants}

The cDNA constructs coding for iPR3-Val ${ }^{103}$ and $\mathrm{iHm} 5-\mathrm{Val}^{103}$ and their expression in HEK293 cells were described in detail elsewhere $[19,26]$. Both mutants carry a carboxyterminal cmyc-peptide extension and a poly-His peptide extension for anchoring in solid phase immunoassays and purification using nickel columns from GE Healthcare (Chicago, IL) as previously described and specified below [19, 26-28, 32].

\subsection{Immunoassays}

For Western blots, PR3 mutants were loaded (1 $\mu \mathrm{g} /$ lane) onto 12\% Tris-HCl gels from BioRad (Hercules, CA). Protein samples were not reduced, and SDS gel electrophoresis was performed at 180 volts for 35 minutes. Proteins were transferred from gels to nitrocellulose membranes. Membranes were subsequently washed with TBS buffer, blocked for 45 minutes at room temperature (RT) with TBS / $0.2 \%$ non-fat dry milk. Next, membranes were washed twice with TBS / 0.1\% Tween 20. Monoclonal antibodies, diluted to $0.5-1.0 \mu \mathrm{g} / \mathrm{mL}$ as indicated, were incubated on the membrane overnight at $4{ }^{\circ} \mathrm{C}$. Next, membranes were washed twice with TBS / 0.1\% Tween 20 and incubated with goat anti-human or anti-mouse IgG HRP conjugates, diluted to 1:20,000, for 20 minutes at RT. Membranes were washed again and developed with the 
[Type text]

Pierce ECL Western Blotting Substrate kit from Thermo Fisher Scientific (Waltham, MA) according to package insert, and exposed as indicated.

For the direct ELISA experiments, Maxisorp ${ }^{\circledR}$ from Invitrogen (Carlsbad, CA) plates were coated with iHm5-Val ${ }^{103}$ or iPR3-Val ${ }^{103}, 1.0 \mu \mathrm{g} / \mathrm{mL}$, in $\mathrm{NaHCO}_{3}$, overnight at $4{ }^{\circ} \mathrm{C}$. In between steps, plates were washed three times with $200 \mu \mathrm{L}$ of PBS with $0.05 \%$ Tween 20 (10 $\mathrm{mM}$ sodium phosphate, $0.15 \mathrm{M} \mathrm{NaCl}, 0.05 \%$ Tween-20, and $\mathrm{pH} 7.5)$. The plates were then blocked with $200 \mu \mathrm{L}$ of PBS with 1\% Tween 20 and 10\% BSA diluted to 1:10 for 2 hours, at RT and protected from direct light exposure. moANCA518 or epitope specific anti-PR3 moAbs (1.0 $\mu \mathrm{g} / \mathrm{mL}$ ) were diluted to 1:20 in PBS with $1 \%$ Tween 20 and 10\% BSA and used as primary antibodies. The antibody binding to the PR3 mutants was probed with HRP-conjugated antihuman IgG antibody (1:250 dilution) incubated for 1 hour at RT. As substrate, $100 \mu \mathrm{L}$ of 3,3',5,5'-tetramethylbenzidine (TMB, Thermo Fisher Scientific () ) was developed for 15 minutes and stopped with $100 \mu \mathrm{L} 2 \mathrm{~N} \mathrm{H}_{2} \mathrm{SO}_{4}$. The absorbance in optical density (OD) was measured using spectrophotometry at $450 \mathrm{~nm}$. Results are expressed as the net absorbance in OD after subtraction of the absorbance readings of the background wells coated with $\mathrm{NaHCO}_{3}$ only. Alternatively, epitope specific anti-PR3 moAbs (see below) were coated to Maxisorp® plates at concentrations of $2.0-4.0 \mu \mathrm{g} / \mathrm{mL}$ in $\mathrm{NaHCO}_{3}$ overnight at $4{ }^{\circ} \mathrm{C}$ to capture the PR3 mutants.

The anchor ELISA method for IgG PR3-ANCAs was described previously for IgA PR3ANCAs [32] and is conceptually similar to the capture ELISA utilizing the $C$-terminal cmycpeptide extension of a PR3 mutant [26, 27]. Either the purified PR3 mutants or culture media supernatants from PR3 mutant expressing 293 cell clones diluted in IRMA buffer (50 mM Tris, $0.1 \mathrm{M} \mathrm{NaCl}, \mathrm{pH} 7.4$, and $0.1 \% \mathrm{BSA}$ ) were incubated in Pierce ${ }^{\circledR}$ nickel-coated plates from Thermo Fisher Scientific (Waltham, CA) for 1 hour at RT; the background wells were incubated 
[Type text]

with serum-free media instead $[26,27,32]$. Plates were washed three times with TBS wash buffer (20 mM Tris, $500 \mathrm{mM} \mathrm{NaCl}, \mathrm{pH} 7.5$, and 0.05\% Tween 20) in between steps. Serum samples were diluted 1:20 in TBS buffer containing 0.5\% BSA and incubated with the antigen for 1 hour at RT. PR3-ANCAs were detected after incubation for 1 hour at RT with alkaline phosphatase-conjugated goat anti-human $\operatorname{IgG}$ (1:10,000 dilution). When required, IgA and $\operatorname{IgM}$ PR3-ANCAs were detected using alkaline phosphatase-conjugated goat anti-human IgA, (1:2,000 dilution) and goat anti-human IgM ( $\mu$-chain specific)-alkaline phosphatase antibody (1:20,000), respectively. $P$-Nitrophenyl phosphate was used as substrate at a concentration of 1 $\mathrm{mg} / \mathrm{mL}$. The net absorbance was obtained by spectrophotometry at $405 \mathrm{~nm}$ after 30 minutes of exposure. The assay's cut-off value for a positive result was defined as the mean net absorbance obtained from 30 normal control serum samples plus 2 standard deviations of the mean. The net absorbance cut-off values for IgG PR3-ANCA detection using iPR3-Val ${ }^{103}$ and iHm5-Val ${ }^{103}$ were determined as 0.105 and 0.107 OD, respectively.

\subsection{Serum samples}

The 30 serum samples from normal donors used for the determination of the normal (negative) range of the anchor ELISA for PR3-ANCA detection using the PR3 mutants as antigen were obtained from the Clinical Immunology Laboratory of Mayo Clinic, Rochester, MN. Three hundred serum samples from healthy octogenarians used for the specificity analyses were obtained from the Mayo Clinic Biospecimen repository. No patient identifiers or clinical data about these individuals were available to the investigators. The use of these serum samples for this study was approved by the Mayo Clinic Institutional Review Board. 
[Type text]

Serum samples from patients with ANCA-associated vasculitis used in this study were collected during the Wegener's Granulomatosis Etanercept Trial (WGET) and during the Rituximab versus Cyclophosphamide for ANCA-Associated Vasculitis trial (RAVE). Details of the WGET and RAVE protocols, patient characteristics and trial results were described elsewhere [33-35]. Participants of both trials had provided written consent for the use of their serum samples in ancillary studies.

\subsection{Generation of moANCA518}

DNA barcode-enabled sequencing of the antibody repertoire was performed on plasmablasts derived from 5 participants in the RAVE study at baseline, at time of remission and at time of subsequent relapse as described for rheumatoid arthritis and Sjögren syndrome [36, 37]. Phylograms of the antibody repertoires revealed clonal families of affinity matured antibodies with shared heavy and light chain VJ usage, and 25 antibodies were selected for recombinant expression [36]. These 25 recombinant human monoclonal antibodies were tested for reactivity with ANCA target antigens, including MPO [32], human neutrophil elastase (HNE) [38-40], iPR3-Val ${ }^{103}$, and $\mathrm{iHm} 5-\mathrm{Val}^{103}$ in parallel, by the anchor ELISA using recombinant antigens carrying a $C$-terminal poly-His tag.

\subsection{Monoclonal antibodies and antigen-binding fragments}

The moAb PR3G-2 (targeting Epitope 1) was obtained from the Kallenberg group, and the moAb WGM2 (targeting Epitope 3) was purchased from Hycult Biotech Inc. (Wayne, PA) $[19,41,42]$. The moAbs MCPR3-2 (targeting Epitope 4), MPR3-3 (targeting Epitope 3) and 
[Type text]

MCPR3-7 (targeting Epitope 5) that were generated by the Specks group were described and characterized in detail elsewhere [19, 24, 26].

The Pierce ${ }^{\mathrm{TM}}$ Fab Preparation Kit from Thermo Fisher Scientific was used to generate the antigen-binding fragment (Fab) from $1.0 \mathrm{mg}$ of a moAb (moANCA518, MCPR3-2, MCPR3-3, or MCPR3-7) following the manufacturer's protocol.

\subsection{Statistical analysis}

IBM $^{\circledR}$ SPSS $^{\circledR}$ Statistics for MacOS, version 25 (IBM, Armonk, NY, USA) was used to calculate the means and standard errors of 3-5 repeat experiments and to compare the means between groups with the two-tailed paired $t$-test.

\section{Results}

\subsection{Preferential binding of PR3-ANCAs to iHM5-Val ${ }^{103}$ over iPR3-Val ${ }^{103}$}

Using the net absorbance as a measure of the reactivity of a serum sample with an antigen, we found that the reactivities of IgG PR3-ANCA positive serum samples with iHm5$\mathrm{Val}^{103}$ were either equal or higher than those with iPR3-Val ${ }^{103}$ in an anchor ELISA (Fig. 2). Of the 178 serum samples obtained from the WGET participants at enrollment, 148 had previously tested positive for PR3-ANCA in at least one of several immunoassays for PR3-ANCAs [33]. By the anchor ELISA, 144 samples tested positive for IgG PR3-ANCAs with iHm5-Val ${ }^{103}$, and 135 were positive with iPR3-Val ${ }^{103}$ (Table 1 and Supplementary Figure). Of the 135 samples that reacted with both antigens, $108(80 \%)$ had higher reactivities with iHm5-Val ${ }^{103}$ than with iPR3-Val ${ }^{103}$, and $41(30 \%)$ of the samples had reactivities with iHm5-Val ${ }^{103}$ that were more than double the reactivities with iPR3-Val ${ }^{103}$ (Table 1 and Supplementary Figure). 
[Type text]

To confirm these results in an independent cohort, we also analyzed 129 serum samples, which had previously tested positive for PR3-ANCAs in at least one immunoassay and were obtained from the participants in the RAVE study at the time of enrollment $[34,35]$. Of these, 128 samples showed reactivity with $\mathrm{iHm} 5-\mathrm{Val}^{103}$ and 126 samples reacted with both iHm5-Val ${ }^{103}$ and iPR3-Val ${ }^{103}$. The reactivities with $\mathrm{iHm} 5-\mathrm{Val}^{103}$ of $33(26 \%)$ of these 126 samples were more than double the reactivities with iPR3-Val ${ }^{103}$ (Table 1 and Supplementary Figure). The single serum sample from the WGET cohort and the three serum samples from the RAVE cohort that showed higher reactivity with iPR3-Val ${ }^{103}$ than with $\mathrm{iHm} 5-\mathrm{Val}^{103}$ all yielded very high net absorbance values for both antigens, and on repeat testing results were consistenly slightly lower with iHm5-Val ${ }^{103}$ with the differences for each simple being just above the intra-assay coefficient of variance of the assay of 5\% (data not shown).

To further evaluate whether the preferential binding of PR3-ANCA to iHm5-Val ${ }^{103}$ over iPR3-Val ${ }^{103}$ is of potential clinical utility, we explored the sensitivity and specificity of the anchor ELISA using iHm5-Val ${ }^{103}$ in defined cohorts.

Of the 14 WGET participants who had previously consistently tested negative for PR3ANCAs in other assays [28], enrollment serum samples of two patients (14\%) were positive in the anchor ELISA using $\mathrm{iHm} 5-\mathrm{Val}^{103}$, indicating that in a sizable number of patients with GPA that were previously labeled as "ANCA-negative," PR3-ANCA can be detected with the iHm5$\mathrm{Val}^{103}$ mutant. By contrast, among $52 \mathrm{MPO}-\mathrm{ANCA}$ positive participants of the RAVE study, a patient population not expected to have PR3-ANCAs, two (3.8\%) serum samples tested positive (net absorbances of 0.625 and 0.125 OD, respectively) in the anchor ELISA using iHm5-Val ${ }^{103}$ and negative when using iPR3-Val ${ }^{103}$. 
[Type text]

We also determined the prevalence of PR3-ANCAs in a population of 300 octogenarians without AAV by the anchor ELISA using iHm5-Val ${ }^{103}$ and iPR3-Val ${ }^{103}$ because the frequency of autoantibodies without a corresponding disease is reportedly increasing with age [43]. Only one sample from this population showed weak IgG PR3-ANCA reactivity with iHm5-Val ${ }^{103}$ by the anchor ELISA (net absorbance of 0.173 OD), and two different patients showed reactivity using iPR3-Val ${ }^{103}$ (net absorbances of 0.115 and 0.245 OD, respectively).

To determine whether using $\mathrm{iHm} 5-\mathrm{Val}^{103}$ in the anchor ELISA would allow an earlier detection of PR3-ANCA seroconversion during serial follow-up of patients with AAV, we compared the seroconversion patterns of 33 participants from the WGET and found that PR3ANCA seroconversion detected by the anchor ELISA using iPR3-Val ${ }^{103}$ could not be detected at an earlier quarterly study visit when using iHm5-Val ${ }^{103}$.

We also compared the utility of iHm5-Val ${ }^{103}$ to iPR3-Val ${ }^{103}$ for IgA and IgM PR3-ANCA detections by the anchor ELISA and found similar preferential binding of IgA and IgM PR3ANCAs to iHm5-Val ${ }^{103}$ (data not shown).

Taken together, these results indicate preferential reactivity of the majority of PR3ANCA positive serum samples to iHm5-Val ${ }^{103}$ compared with iPR3-Val ${ }^{103}$ and suggest that iHm5-Val ${ }^{103}$ may enable better detection of low-levels of PR3-ANCAs in patients with AAV than iPR3-Val ${ }^{103}$ without significantly increasing the frequency of false positive results in patients without AAV. 
[Type text]

\subsection{Selective binding of moANCA518 to iHm5-Val 103}

Twenty-five human moAbs derived from plasmablasts of patients with PR3-ANCA positive relapsing AAV were screened for binding to ANCA target antigens by the anchor ELISA using iPR3-Val ${ }^{103}, \mathrm{iHm} 5-\mathrm{Val}^{103}$, and two other ANCA-targeting antigens (MPO and $\mathrm{HNE}$ ). Interestingly, we found that one such moAb (moANCA518) exhibited concentrationdependent binding to iHm5-Val ${ }^{103}$ in the anchor ELISA (Fig. 3A), whereas none of these moAbs bound to iPR3-Val ${ }^{103}$, MPO, or HNE. We confirmed the binding of moANCA518 to iHm5$\mathrm{Val}^{103}$ but not to iPR3-Val ${ }^{103}$ by Western blot under non-reducing conditions (Fig. 3B). We also confirmed the selective binding of moANCA518 to $\mathrm{iHm} 5-\mathrm{Val}^{103}$ over iPR3-Val ${ }^{103}$ in a direct ELISA (Fig. 3C). By contrast, murine anti-PR3 moAbs (PR3G-2, MCPR3-3 and WGM2) exhibited equal binding to both antigens in the direct ELISA (Fig 3D).

\subsection{Remote-mutation-induced selective binding of moANCA518 to Epitope 3 on iHm5- $\operatorname{Val}^{103}$}

To identify the epitope(s) recognized by moANCA518 on $\mathrm{iHm} 5-\mathrm{Val}{ }^{103}$ in a capture ELISA, we used epitope-specific moAbs to capture $\mathrm{iHm} 5-\mathrm{Val}^{103}$ and block or modulate the binding of moANCA518 to the epitope that the moAb is raised against [19]. We found that PR3G-2, a moAb that recognizes Epitope 1 of PR3 [41], did not affect binding of moANCA518 to iHm5-Val ${ }^{103}$; whereas MCPR3-3 or WGM2, both of which recognize Epitope 3 of PR3 [19], respectively decreased or abolished the moANCA518 binding $(p<0.01$; Fig. 4A). When using a PR3-ANCA-containing serum sample obtained from the same patient at the same study visit, from which the plasmablast expressing moANCA518 was generated, we observed similar effects 
[Type text]

of these moAbs on the reactivity of the PR3-ANCA serum sample with iHm5-Val ${ }^{103}$ (Fig. 4B).

These findings identified Epitope 3 on $\mathrm{iHm} 5-\mathrm{Val}^{103}$ as the epitope for moANCA518 and for a significant proportion of PR3-ANCA present in the serum obtained at the same time as the moANCA518-generating plasmablast.

We further confirmed Epitope 3 of $\mathrm{iHm} 5-\mathrm{Val}^{103}$ as the primary target for moANCA518 using Fabs from epitope-specific moAbs as inhibitors of binding of moANCA518 to iHm5$\mathrm{Val}^{103}$ using the anchor ELISA (Fig. 5A). As expected, we observed the strongest inhibition when the Fab from moANCA518 was used to inhibit the moANCA518 binding. A strong inhibition was observed with the Fab from MCPR3-3 that targets Epitope 3 of PR3 [19], whereas a relatively reduced inhibition was found with the Fab from MCPR3-2 that interacts primarily with Epitope 4 and to some extent with Epitope 3 as well [19, 24]. In addition, we found no effect of the Fab from MCPR3-7, which recognizes Epitope 5 [19, 31], on the moANCA518 binding.

The above results demonstrate that moANCA518 recognizes Epitope 3 on iHm5-Val ${ }^{103}$. More importantly, because Epitope 3 is on the opposite side of the chimeric mutation sites in Epitopes 1 and 5 on iHm5-Val ${ }^{103}$ (Fig. 1) and has the same amino acid sequence as that of Epitope 3 on iPR3-Val ${ }^{103}$, our observation that moANCA518 recognizes Epitope 3 instead of Epitope 1 or 5 further indicates that the moANCA518 binding is conferred by an unexpected increase of the antigenicity in Epitope 3 induced by the distal mutations in Epitopes 1 and 5.

\subsection{Remote-mutation-induced preferential binding of most PR3-ANCAs to Epitope 3 on}

\section{iHm5-Val ${ }^{103}$}


[Type text]

To determine whether other PR3-ANCAs would preferentially bind to Epitope 3 on iHm5-Val ${ }^{103}$ over iPR3-Val ${ }^{103}$ due to the distal mutations in $\mathrm{iHm} 5-\mathrm{Val}^{103}$, we further evaluated serum or plasma samples from patients with AAV that had exhibited significant preferential reactivity with iHm5-Val ${ }^{103}$ over iPR3-Val ${ }^{103}$ as described in Section 3.1, and found that the Fabs from MCPR3-3 and moANCA518 inhibited significantly ( $p=0.001$ and 0.017 , respectively) the reactivity of a representative PR3-ANCA-containing plasma sample to $\mathrm{iHm} 5-\mathrm{Val}^{103}$ in the anchor ELISA (Fig. 5B).

These results indicate that the preferential reactivity of PR3-ANCAs containing serum or plasma samples with iHm5-Val ${ }^{103}$ can at least in part be explained by some PR3-ANCAs in these samples being sensitive to the change of antigenicity in Epitope 3 of iHm5-Val ${ }^{103}$ induced by the distal mutations, just like moANCA518.

\section{Discussion}

In this study we show that about half of all PR3-ANCA positive sera displayed stronger binding to $\mathrm{iHm} 5-\mathrm{Val}^{103}$ than to iPR3-Val ${ }^{103}$, indicating that $\mathrm{iHm} 5-\mathrm{Val}^{103}$ has its clinical relevance and could be used as an antigen for more sensitive immunoassays for PR3-ANCA detection relative to the use of $\mathrm{iPR} 3-\mathrm{Val}{ }^{103}$. Using $\mathrm{iHm} 5-\mathrm{Val}^{103}$ we discovered a new human monoclonal PR3-ANCA, moANCA518, that binds preferentially to Epitope 3 on iHm5-Val ${ }^{103}$ over iPR3-Val ${ }^{103}$ as a consequence of an unexpected increase of the antigencity in Epitope 3 of $\mathrm{iHm} 5-\mathrm{Val}^{103}$ that was induced by the three remote chimeric mutations in Epitopes 1 and 5. Finally, we found that the majority of PR3-ANCA-positive plasma samples from patients with AAV with higher reactivities to $\mathrm{iHm} 5-\mathrm{Val}^{103}$ than to iPR3-Val ${ }^{103}$ also displayed similar preferential binding to Epitope 3 of iHm5-Val ${ }^{103}$ as moANCA518. 
[Type text]

The PR3 variant iPR3-Val ${ }^{103}$ has been used for two decades as a standard PR3 antigen for sensitive and specific PR3-ANCA detection by immunoassay [7, 21, 24-29]. The iHm5-Val ${ }^{103}$ variant and its "inverse"-chimeric counterpart, iMh5-Val ${ }^{103}$ (formerly referred to as Mh5) were originally designed for discontinuous epitope mapping and structure-function analysis studies [19]. When we used iHm5-Val ${ }^{103}$ for the of anti-PR3 moAbs and PR3-ANCAs, we expected that some PR3-ANCA positive sera would display reduced binding to $\mathrm{iHm} 5-\mathrm{Val}^{103}$ which would have allowed the conclusion that some PR3-ANCAs in such a serum sample target Epitope 5 (possibly with Epitope 1 as well). Instead, we identified no loss of binding to iHm5-Val ${ }^{103}$ compared to iPR3-Val ${ }^{103}$ by any PR3-ANCA positive sera from patients with PR3-ANCA positive AAV, but that the sera either bound equally well to both of these antigens or displayed substantially increased binding to $\mathrm{iHm} 5-\mathrm{Val}^{103}$. Consequently, we first addressed the question whether iHm5-Val ${ }^{103}$ represents a useful antigen for more sensitive immunoassays for PR3ANCA detection. We found that low-level PR3-ANCAs can be detected more readily in some patients with PR3-ANCA positive AAV without generating a significant number of false positive results in patients with MPO-ANCA positive vasculitis or octogenarians without AAV.

However, we were unable to detect recurrent PR3-ANCAs earlier in trial participants who had serial follow-up PR3-ANCA measurements at quarterly intervals [33-35]. Whether the use of iHm5-Val ${ }^{103}$ might be clinically useful for early detection of PR3-ANCA seroconversion after rituximab therapy in chronically relapsing patients with PR3-ANCA associated AAV, would require a dedicated prospective study with PR3-ANCA measurements at narrower intervals.

The identification of moANCA518 with selective binding to $\mathrm{iHm} 5-\mathrm{Val}^{103}$ was a fortuitous finding that allowed us to further investigate the observation of increased reactivity of many PR3-ANCA-positive sera with $\mathrm{iHm} 5-\mathrm{Val}^{103}$. The PR3-ANCA response is thought to be 
[Type text]

an oligoclonal immune response as serum samples from patients have been documented to contain PR3-ANCAs binding to more than one epitope $[19,44]$. The systematic analysis of the binding of moANCA518 to iHm5-Val ${ }^{103}$ using moAbs with defined PR3-ANCA epitope recognition as inhibitors of binding led to another surprise, namely, that moANCA518 does not bind to the surface region of PR3 where the mutations that differentiate iHm5-Val ${ }^{103}$ from iPR3$\mathrm{Val}^{103}$ are located, but to Epitope 3 of $\mathrm{iHm} 5-\mathrm{Val}^{103}$ which is located on the opposite side of the iHm5-Val ${ }^{103}$ structure from the side where the mutations were introduced (Fig. 1). Thus, we identified a unique PR3-ANCA reactivity to an epitope that is conserved in its amino-acid sequence, yet must display a substantial structural/dynamic change, sufficient to confer antibody specificity. This effect thus appears akin to an allosteric effect; only in this case, such an allosteric effect is not generated by the distal binding of a ligand but generated by distal mutations.

This type of mutation allosteric effect has implications for the design and interpretation of site-directed mutagenesis studies because mutation effects can go far beyond the mutation sites; in the present case, a site that is $30 \AA$ away from the mutation sites according to the crystal structure of human PR3 [45]. Although further studies are needed to explain how mutations (such as the chimeric mutations in iHm5- $\mathrm{Val}^{103}$ ) can increase the antigenicity of a remote epitope (such as Epitope 3 on $\mathrm{iHm5-Val}{ }^{103}$ ), our present finding that PR3-ANCAs bind to epitopes of a folded rather than denatured antigen that is conducive to the mutation allosteric effect or "cross talk" of mutations suggests a possible mechanism of activation of a latent epitope or potentiation of a weak epitope by distal mutations. This has relevance for the etiologies of antibody-mediated autoimmune diseases and may lead to novel therapeutic approaches aimed at interfering with pathogenic antibody-antigen interactions. 
[Type text]

\section{Conclusions}

This study shows that $\mathrm{iHm} 5-\mathrm{Val}^{103}$ is a clinically relevant PR3 mutant and can be used as an antigen for sensitive PR3-ANCA detection in patients with AAV without significant false positive PR3-ANCA detections in patients without AAV. More importantly, our results demonstrate that the preferential binding of PR3-ANCAs to iHm5-Val ${ }^{103}$ over iPR3-Val ${ }^{103}$ is the result of an increase of the antigenicity of Epitope 3 on iHm5-Val ${ }^{103}$ induced by the distal mutations. Hence, the interpretation of discontinuous epitope mapping and structure-function analysis results derived from in vitro site-specific mutagenesis need to be carefully reconsidered and studied in light of the allosteric effect of the distal mutations. Most importantly, the present work suggests that activation or potentiation of a respective latent or weak epitope by remote mutations may play a role in etiologies of antibody-mediated autoimmune diseases and offer insights into novel treatment strategies for these diseases.

\section{Funding}

This study was supported by funds from the Connor Group Foundation and the Mayo Foundation.

\section{Acknowledgements}

The moAbs MCPR3-3 and MCPR3-7 were generated with the assistance of Thomas G. Beito from the Mayo Clinic Monoclonal Antibody Core Facility. 
bioRxiv preprint doi: https://doi.org/10.1101/549063; this version posted February 14, 2019. The copyright holder for this preprint (which was not certified by peer review) is the author/funder, who has granted bioRxiv a license to display the preprint in perpetuity. It is made available under aCC-BY-NC-ND 4.0 International license.

[Type text]

\section{Appendix A. Supplementary data}

Supplementary information related to this article can be found at .... 
[Type text]

\section{References}

[1] J.C. Jennette, R.J. Falk, P.A. Bacon, N. Basu, M.C. Cid, F. Ferrario, et al., 2012 revised international Chapel Hill consensus conference nomenclature of vasculitides, Arthritis Rheumatol. 65 (2013) 1-11. https://doi.org/10.1002/art.37715.

[2] R.J. Falk, J.C. Jennette, Anti-neutrophil cytoplasmic autoantibodies with specificity for myeloperoxidase in patients with systemic vasculitis and idiopathic necrotizing and crescentic $\begin{array}{llllll}\text { glomerulonephritis, } & \text { N. } & \text { Engl. } & \text { J. } & \text { Med. } & 318 \quad \text { (1988) }\end{array}$ https://doi.org/10.1056/NEJM198806233182504.

[3] D.E. Jenne, J. Tschopp, J. Lüdemann, B. Utecht, W.L. Gross, Wegener's autoantigen decoded, Nature. 346 (1990) 520. https://doi.org/10.1038/346520a0.

[4] G.S. Hoffman, U. Specks, Antineutrophil cytoplasmic antibodies, Arthritis Rheumatol. 41 (1998) 1521-1537. https://doi.org/10.1002/1529-0131(199809)41:9<1521::AID-ART2>3.0.CO;2-A.

[5] X. Bossuyt, J.W. Cohen Tervaert, Y. Arimura, D. Blockmans, L.F. Flores-Suarez, L. Guillevin, et al., Position paper: revised 2017 international consensus on testing of ANCAs in granulomatosis with polyangiitis and microscopic polyangiitis, Nat. Rev. Rheumatol. 13 (2017) 683-692, https://doi.org/10.1038/nrrheum.2017.140.

[6] D. Cornec, E. Cornec-Le Gall, F.C. Fervenza, U. Specks. ANCA-associated vasculitis - clinical utility of using ANCA specificity to classify patients, Nat. Rev. Rheumatol. 12 (2016) 570-579. https://doi.org/10.1038/nrrheum.2016.123.

[7] L.A. Fussner, A.M. Hummel, D.R. Schroeder, F. Silva, R. Cartin-Ceba, M.R. Snyder, et al., Factors determining the clinical utility of serial measurements of antineutrophil cytoplasmic antibodies targeting proteinase 3, Arthritis Rheumatol. 68 (2016) 1700-1710. https://doi.org/10.1002/art.39637.

[8] M.J. Kemna, J. Damoiseaux, J. Austen, B. Winkens, J. Peters, P. van Paassen, et al., ANCA as a predictor of relapse: useful in patients with renal involvement but not in patients with nonrenal disease, J. Am. Soc. Nephrol. 26 (2015) 537-542. https://doi.org/10.1681/ASN.2013111233.

[9] C.G. Kallenberg, Pathogenesis of PR3-ANCA associated vasculitis, J. Autoimmun. 30 (2008) 29-36. https://doi.org/10.1016/j.jaut.2007.11.005

[10] U. Schönermarck, E. Csernok, W.L. Gross, Pathogenesis of anti-neutrophil cytoplasmic antibodyassociated vasculitis: challenges and solutions 2014, Nephrol. Dial. Transplant. 30 (2015) Suppl 1:i46-52. https://doi.org/10.1093/ndt/gfu398

[11] H.L. Hutton, S.R. Holdsworth, A.R. Kitching, ANCA-Associated Vasculitis: Pathogenesis, Models, and Preclinical Testing, Semin. Nephrol. $37 \quad$ (2017) 418-435. https://doi.org/10.1016/j.semnephrol.2017.05.016

[12] P. Bini, J.E. Gabay, A. Teitel, et al., Antineutrophil cytoplasmic autoantibodies in Wegener's granulomatosis recognize conformational epitope(s) on proteinase 3, J. Immunol. 149 (1992) 1409-1415.

[13] Y.M. van der Geld, W. Oost-Kort, P.C. Limburg, U. Specks, C.G. Kallenberg, Recombinant proteinase 3 produced in different expression systems: recognition by anti-PR3 antibodies, J. Immunol. Methods. 244 (2000) 117-131. https://doi.org/10.1016/S0022-1759(00)00261-1. 
bioRxiv preprint doi: https://doi.org/10.1101/549063; this version posted February 14, 2019. The copyright holder for this preprint (which was not certified by peer review) is the author/funder, who has granted bioRxiv a license to display the preprint in perpetuity. It is made available under aCC-BY-NC-ND 4.0 International license.

[Type text]

[14] U. Specks, What you should know about PR3-ANCA Conformational requirements of proteinase 3 (PR3) for enzymatic activity and recognition by PR3-ANCA, Arthritis Res. 2 (2000) 263-267. https://doi.org/10.1186/ar99.

[15] R.C. Williams Jr., C.C. Malone, J. Payabyab, L. Byres, D. Underwood, Epitopes on proteinase-3 recognized by antibodies from patients with Wegener's granulomatosis, J. Immunol. 152 (1994) 47224737.

[16] Y.M. van der Geld, P.C. Limburg, C.G. Kallenberg, Proteinase 3, Wegener's autoantigen: from gene to antigen, J. Leukoc. Biol. 69 (2001) 177-190. https://doi.org/10.1189/jlb.69.2.177.

[17] M.E. Griffith, A. Coulthart, S. Pemberton, A.J.T. George, C.D. Pusey, Anti-neutrophil cytoplasmic antibodies (ANCA) from patients with systemic vasculitis recognize restricted epitopes of proteinase 3 involving the catalytic site, Clin. Exp. Immunol. 123 (2001) 170-177. https://doi.org/10.1046/j.13652249.2001.01420.x.

[18] B.F. Bruner, E.S. Vista, D.M. Wynn, J.B. Harley, J.A. James, Anti-neutrophil cytoplasmic antibodies target sequential functional proteinase 3 epitopes in the sera of patients with Wegener's granulomatosis, Clin. Exp. Immunol. 162 (2010) 262-270. https://doi.org/10.1111/j.1365-2249.2010.04251.x.

[19] F. Silva, A.M. Hummel, D.E. Jenne, U. Specks, Discrimination and variable impact of ANCA binding to different surface epitopes on proteinase 3, the Wegener's autoantigen, J. Autoimmun. 35 (2010) 299-308. https://doi.org/10.1016/j.jaut.2010.06.021.

[20] K.M. Dolman, A. Jager, A. Sonnenberg, A. von dem Borne, R. Goldschmeding, Proteolysis of classic anti-neutrophil cytoplasmic autoantibodies (C-ANCA) by neutrophil proteinase 3, Clin. Exp. Immunol. 101 (1995) 8-12. https://doi.org/10.1111/j.1365-2249.1995.tb02269.x.

[21] U. Specks, D.N. Fass, M.P. Fautsch, A.M. Hummel, M.A. Viss, Recombinant human proteinase 3, the Wegener's autoantigen, expressed in HMC-1 cells is enzymatically active and recognized by cANCA. FEBS Letters. 390 (1996) 265-270. https://doi.org/10.1016/0014-5793(96)00669-2.

[22] J. Sun, D.N. Fass, M.A. Viss, A.M. Hummel, H. Tang, H.A. Homburger, U. Specks, A proportion of proteinase 3 (PR3)-specific anti-neutrophil cytoplasmic antibodies (ANCA) only react with PR3 after cleavage of its N-terminal activation dipeptide, Clin. Exp. Immunol. 114 (1998) 320-326. https://doi.org/10.1046/j.1365-2249.1998.00730.x.

[23] M. Gencik, S. Meller, S. Borgmann, H. Fricke, Proteinase 3 gene polymorphisms and Wegener's granulomatosis, Kidney Int. 58 (2000) 2473-2477. https://doi.org/10.1016/j.1365-2249.1998.00730.x.

[24] J. Sun, D.N. Fass, J.A. Hudson, M.A. Viss, J. Wieslander, H.A. Homburger, U. Specks, CaptureELISA based on recombinant PR3 is sensitive for PR3-ANCA testing and allows detection of PR3 and PR3-ANCA rPR3 immunecomplexes, J. Immunol. Methods. 211 (1998) 111-123. https://doi.org/10.1016/S0022-1759(97)00203-2.

[25] K.A. Russell, E. Wiegert, D.R. Schroeder, H.A. Homburger, U. Specks, Detection of anti-neutrophil cytoplasmic antibodies under actual clinical testing conditions, Clin. Immunol. 103 (2002) 196-203. https://doi.org/10.1006/clim.2001.5200. 
bioRxiv preprint doi: https://doi.org/10.1101/549063; this version posted February 14, 2019. The copyright holder for this preprint (which was not certified by peer review) is the author/funder, who has granted bioRxiv a license to display the preprint in perpetuity. It is made available under aCC-BY-NC-ND 4.0 International license.

[Type text]

[26] S.A. Capizzi, M. Viss, A.M. Hummel, D.N. Fass, U. Specks, Effects of carboxy-terminal modifications of proteinase 3 (PR3) on the recognition by PR3-ANCA, Kidney Int. 63 (2003) 756-760. https://doi.org/10.1046/j.1523-1755.2003.00765.x

[27] A.S. Lee, J.D. Finkielman, T. Peikert, A.M. Hummel, M.A. Viss, U. Specks, A novel capture-ELISA for detection of anti-neutrophil cytoplasmic antibodies (ANCA) based on c-myc peptide recognition in carboxy-terminally tagged recombinant neutrophil serine proteases, J. Immunol. Methods. 307 (2005) 6272. https://doi.org/10.1016/j.jim.2005.09.004.

[28] J.D. Finkielman, A.S. Lee, A.M. Hummel, M.A. Viss, G.L. Jacob, H.A. Homburger HA, et al., ANCA are detectable in nearly all patients with active severe Wegener's granulomatosis, Am. J. Med. 120 (2007) 643e9-643e14. https://doi.org/10.1016/j.amjmed.2006.08.016.

[29] J.D. Finkielman, P.A. Merkel, D.R. Schroeder, G.S. Hoffman, R. Spiera, E.W. St. Clair, et al., for the WGET Research Group. Antiproteinase 3 Antineutrophil Cytoplasmic Antibodies and Disease Activity in Wegener Granulomatosis, Ann. Intern. Med. 147 (2007) 611-619. https://doi.org/10.7326/0003-4819-147-9-200711060-00005.

[30] B. Korkmaz, A. Kuhl, B. Bayat, S. Santoso, D.E. Jenne, A hydrophobic patch on proteinase 3, the target of autoantibodies in Wegener granulomatosis, mediates membrane binding via NB1 Receptors, J. Biol. Chem. 283 (2008) 35976-35982. https://doi.org/10.1074/jbc.M806754200.

[31] L.C. Hinkofer, S.A. Seidel, B. Korkmaz, F. Silva, A.M. Hummel, D. Braun, et al., A monoclonal antibody (MCPR3-7) interfering with the activity of proteinase 3 by an allosteric mechanism, J. Biol. Chem. 288 (2013) 26635-26648. https://doi.org/10.1074/jbc.M113.495770.

[32] E. Oommen, A.M. Hummel, L. Allmannsberger, D. Cuthbertson, S. Carette, C. Pagnoux, et al., IgA antibodies to myeloperoxidase in patients with eosinophilic granulomatosis with polyangiitis (ChurgStrauss), Clin. Exp. Rheumatol. 35 (2017) 98-101.

[33] The Wegener's Granulomatosis Etanercept Trial (WGET) research group. Etanercept plus standard therapy for Wegener's granulomatosis, N. Engl. J. Med. 352 (2005) 351-361. https://doi.org/10.1056/NEJMoa041884.

[34] J. Stone, P.A. Merkel, R. Spiera, P. Seo, C.A. Langford, G.S. Hoffman, et al., Rituximab versus cyclophosphamide for ANCA-associated vasculitis, N. Engl. J. Med. 363 (2010) 221-232. https://doi.org/10.1056/NEJMoa0909905.

[35] U. Specks, P.A. Merkel, P. Seo, R. Spiera, C.A. Langford, G.S. Hoffman, et al., Efficacy of remission-induction regimens for ANCA-associated vasculitis. N. Engl. J. Med. 369 (2013) 417-427. https://doi.org/0.1056/NEJMoa1213277.

[36] Y.C. Tan, S. Kongpachith, L.K. Blum, C.H. Ju, L.J. Lahey, D.R. Lu, et al., Barcode-enabled sequencing of plasmablast antibody repertoires in rheumatoid arthritis, Arthritis Rheumatol. 66 (2014) 2706-2715. https://doi.org/10.1002/art.38754.

[37] U. Hershberg, W. Meng, B. Zhang, N. Haff, E.W. St Clair, P.L. Cohen, et al., Persistence and selection of an expanded B-cell clone in the setting of rituximab therapy for Sjögren's syndrome, Arthritis Res. Ther. 16 (2014) R51. https://doi.org/10.1186/ar4481. 
[Type text]

[38] T. Peikert, J.D. Finkielman, A.M. Hummel, M.E. McKenney, G. Gregorini, M. Trimarchi, et al., Functional characterization of antineutrophil cytoplasmic antibodies in patients with cocaine-induced midline destructive lesions, Arthritis Rheum. 58 (2008) 1546-1551.Preferential-Binding-to-iHm5Val103_J-Autoimmun_011419_FINALypp.rtf https://doi.org/10.1002/art.23469.

[39] O. Wiesner, K.A. Russell, A.S. Lee, D.E. Jenne, M. Trimarchi, G. Gregorini, et al., Antineutrophil cytoplasmic antibodies reacting with human neutrophil elastase as a diagnostic marker for cocaineinduced midline destructive lesions but not autoimmune vasculitis, Arthritis Rheumatol. 50 (2004) 29542965. https://doi.org/10.1002/art.20479.

[40] O. Wiesner, R.D. Litwiller, A.M. Hummel, M.A. Viss, C.J. McDonald, D.E. Jenne, et al., Differences between human proteinase 3 and neutrophil elastase and their murine homologues are relevant for murine model experiments, FEBS Lett. 579 (2005) 5305-5312. https://doi.org/10.1016/j.febslet.2005.08.056.

[41] Y.M. van der Geld, P.C. Limburg, C.G. Kallenberg, Characterization of monoclonal antibodies to proteinase 3 (PR3) as candidate tools for epitope mapping of human anti-PR3 autoantibodies, Clin. Exp. Immunol. 118 (1999) 487-496. https://doi.org/10.1046/j.1365-2249.1999.01079.x.

[42] E. Csernok, J. Lüdemann, W.L. Gross, D.F. Bainton, Ultrastructural localization of proteinase 3, the target antigen of anti-cytoplasmic antibodies circulating in Wegener's granulomatosis, Am. J. Pathol. 137 (1990) 1113-1120.

[43] K. Andersen-Ranberg, M. HØier-Madsen M, A. Wiik, B. Jeune, L. Hegedus. High prevalence of autoantibodies among Danish centenarians, Clin. Exp. Immunol. 138 (2004) 158-163. https://doi.org/0.1111/j.1365-2249.2004.02575.x.

[44] Y.M. van der Geld, C.A. Stegeman, C.G. Kallenberg, B cell epitope specificity in ANCA-associated vasculitis: does it matter?, Clin. Exp. Immunol. 137 (2004) 451-459. https://doi.org/10.1111/j.1365$\underline{2249.2004 .02572 . \mathrm{x}}$

[45] M. Fujinaga, M.M. Chernaia, R. Halenbeck, K. Koths, M.N.G. James, The crystal structure of PR3, a neutrophil serine proteinase antigen of Wegener's granulomatosis antibodies, J. Mol. Biol. 261 (1996) 267-278. https://doi.org/10.1006/jmbi.1996.0458. 
[Type text]

\section{Figure legends}

Fig. 1 - Cartoon model of human proteinase 3 (PR3-Val $\left.{ }^{103}\right)^{*}$. The left panel shows PR3$\mathrm{Val}^{103}$ in the standard orientation facing the active site pocket; the right panel shows PR3-Val ${ }^{103}$ with an about 90 degree rotation. The catalytic triad of this neutrophil serine protease comprises His57, Asp102, and Ser195. Ala146, Trp218, and Leu223 in PR3-Val ${ }^{103}$ shown here are replaced by their hydrophilic murine counterparts (Thr146, Arg218, and Gln223) in iHm5-Val ${ }^{103}$. Shown in red is Epitope 3 on the opposite side of the PR3-Val ${ }^{103}$ structure from the side where the mutations were introduced. (*Generated using PyMOL v. 1.7.0.3, Schroedinger, LLC)

\section{Fig. 2 - Reactivity of PR3-ANCA positive serum samples with iHm5-Val ${ }^{103}$ and iPR3-Val ${ }^{103}$.} Representative examples of serum samples from patients with PR3-ANCA associated vasculitis showing higher $(\mathbf{A}$ and $\mathbf{B})$ or equal $(\mathbf{C}$ and $\mathbf{D})$ binding to iHm5-Val ${ }^{103}$ compared to iPR3-Val ${ }^{103}$ in the anchor ELISA.

\section{Fig. 3 - Selective binding of moANCA518 to iHm5-Val ${ }^{103}$ over iPR3-Val ${ }^{103}$.}

A. Dilution curves for the binding of moANCA518 to iHm5-Val ${ }^{103}$ (solid line) and iPR3-Val ${ }^{103}$ (dashed line) in the anchor ELISA. Dose-dependent binding to $\mathrm{iHm} 5-\mathrm{Val}^{103}$ was detected, whereas no binding to iPR3-Val ${ }^{103}$ could be detected even at the highest concentration. B. Western blot. B.1. Control Western blot documenting comparable loading of iPR3-Val ${ }^{103}$ and $\mathrm{iHm} 5-\mathrm{Val}^{103}$ when probed with $1.0 \mu \mathrm{g} / \mathrm{mL}$ murine anti c-myc moAb showing the binding of the 
[Type text]

anti-c-myc moAb to the c-myc-peptide of the carboxy-terminal tag of the PR3 mutants. B.2. No significant binding of moANCA518 to iPR3-Val ${ }^{103}$ and strong binding to iHm5-Val ${ }^{103}$ were found when the proteins were probed with $0.5 \mu \mathrm{g} / \mathrm{mL}$ human moANCA518. C. Use of the antigens $\mathrm{iHm} 5-\mathrm{Val}^{103}$ and $\mathrm{iPR} 3-\mathrm{Val}^{103}$ in a direct ELISA showed binding of moANCA518 to iHm5-Val ${ }^{103}$ (black bar) but not to iPR3-Val ${ }^{103}$ (white bar). D. Binding of the mouse moAbs PR3G-2, MCPR3-3, and WGM2 to iHm5-Val ${ }^{103}$ (black bars) and iPR3-Val'103 (white bars) in the direct ELISA. The absorbances at $450 \mathrm{~nm}$ for the binding to iHm5-Val ${ }^{103}$ and iPR3-Val ${ }^{103}$ were similar for all moAbs. ELISA - enzyme-linked immunosorbent assay; HRP - horseradish peroxidase; moAb - monoclonal antibody.

\section{Fig. 4 - Identification of Epitope 3 of iHm5-Val ${ }^{103}$ as a target of moANCA518 and PR3-}

\section{ANCA.}

A. Inhibition of the moANCA518 binding to $\mathrm{iHm} 5-\mathrm{Val}^{103}$ using different moAbs was assessed by capture ELISA. The moAbs PR3G-2, MCPR3-3, and WGM2 $(2,4$, and $4 \mu \mathrm{g} / \mathrm{mL}$, respectively) were coated to the plate and used to capture the antigen, $\mathrm{iHm} 5-\mathrm{Val}{ }^{103}$. moANCA518 $(1.0 \mu \mathrm{g} / \mathrm{mL})$ was used as primary antibody. The binding of moANCA518 to iHm5-Val ${ }^{103}$ was impaired significantly when the moAbs MCPR3-3 and WGM2 recognizing Epitope 3 were used to capture the antigen, compared to PR3G-2 which binds to Epitope 1.

B. Serum obtained at the same study visit of the patient from which the plasmablasts were isolated which led to the development of moANCA518, showed similar differential reactivity of PR3-ANCA with iHm5-Val ${ }^{103}$ depending on the choice of moAb used to capture the antigen. Results were similar when purified iHm5-Val ${ }^{103}$ antigen [black bars] or the crude iHm5-Val ${ }^{103}$ 
[Type text]

antigen contained in media supernatant from cells expressing the recombinant antigen [white bars] were used.

Fig. 5 - Inhibition of the binding of moANCA518 and PR3-ANCA reactivity with iHm5Val ${ }^{103}$ by epitope-specific Fabs.

A. Use of Fabs $(2 \mu \mathrm{g} / \mathrm{mL})$ from epitope specific moAbs as competitors of binding of moANCA518 to iHm5-Val ${ }^{103}$ used as antigen in the anchor ELISA. A significant reduction of binding of moANCA518 to iHm5-Val ${ }^{103}$ was observed after incubation with self (moANCA518 Fab) and Fabs that bind to Epitope 3 (MCPR3-3). There was no effect of incubation with Fabs from MCPR3-7 which binds to Epitope 5 of iPR3-Val ${ }^{103}$. Some inhibition of binding was also observed with Fabs from MCPR3-2 which binds primarily to Epitope 4, but has previously shown some mild competition with some moAbs binding to Epitope 3 [19]. The control corresponds to incubation with TBS without Fab. ELISA - enzyme-linked immunosorbent assay; moAb - monoclonal antibody; TBS - tris-buffered saline.

B. A representative PR3-ANCA positive patient plasma sample was selected from a cohort based on the differential binding results displayed to iHm5-Val ${ }^{103}$ and iPR3-Val ${ }^{103}$ in the anchor ELISA. Epitope specificity of the Fabs from moAbs used as inhibitors of binding is as follows: MCPR3-3 for Epitope 3, MCPR3-2 for Epitope 4 and part of Epitope 3, and MCPR3-7 for Epitope 5. The control Fab corresponds to a mouse IgG1 Fab. Inhibition of PR3-ANCA binding to iHm5-Val ${ }^{103}$ by Fabs that bind Epitope 3 was observed: MCPR3-3 ( $p=0.001$, in comparison with the control) and moANCA518 ( $p=0.017$, in comparison with the control). Fab - antigen binding fragment; moAb - monoclonal antibody; OD - optical density. 
bioRxiv preprint doi: https://doi.org/10.1101/549063; this version posted February 14, 2019. The copyright holder for this preprint (which was not certified by peer review) is the author/funder, who has granted bioRxiv a license to display the preprint in perpetuity. It is made available under aCC-BY-NC-ND 4.0 International license.

\section{Figure 1}
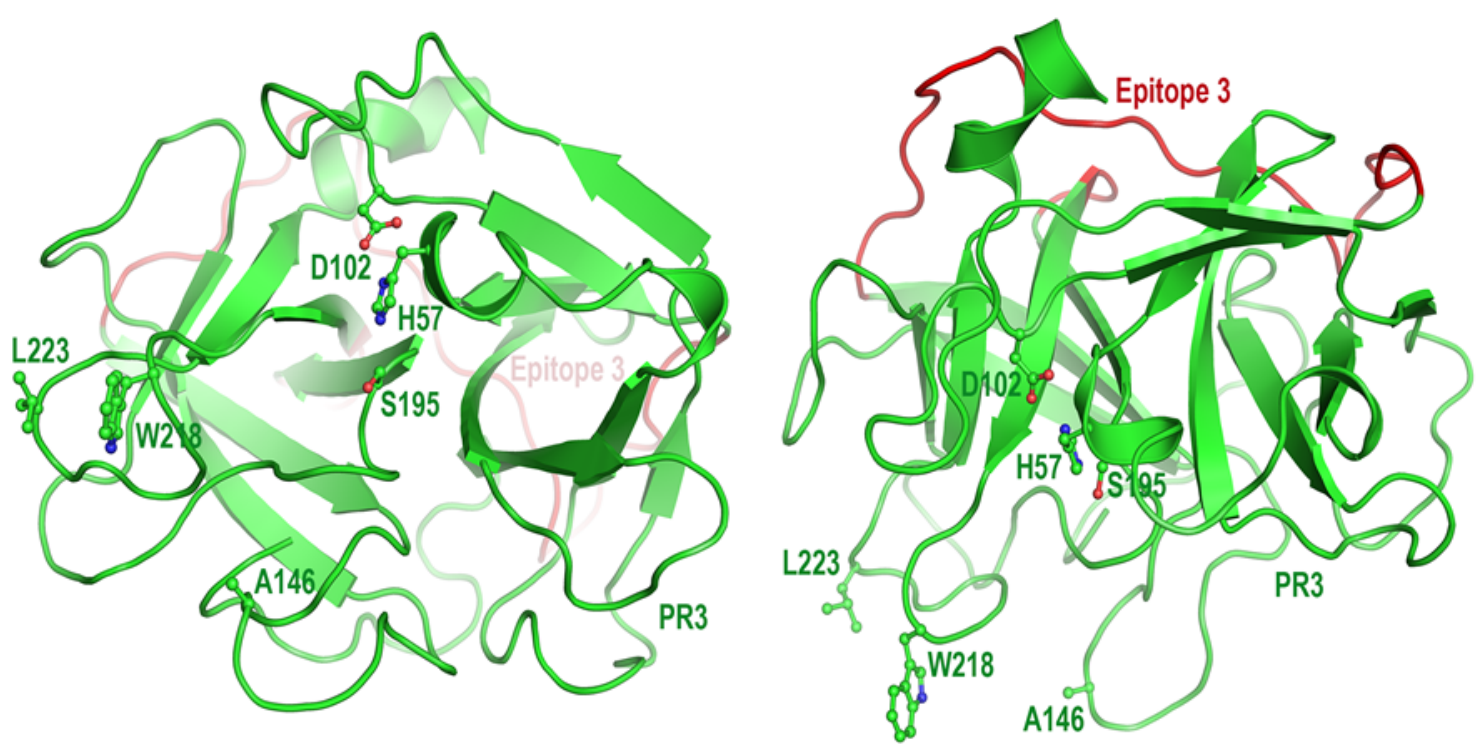
Figure 2

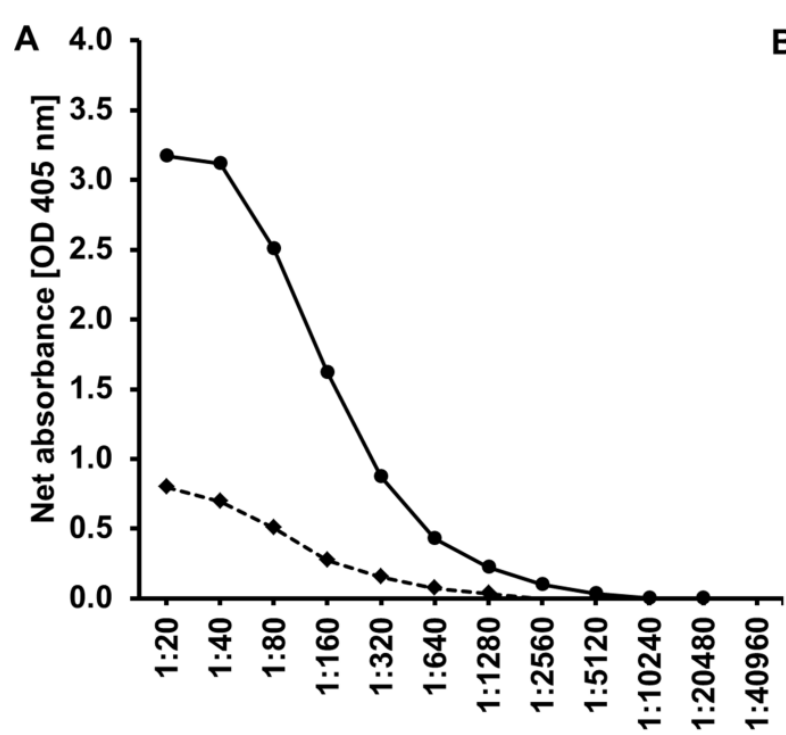

Patient 1 serum dilutions [titer]

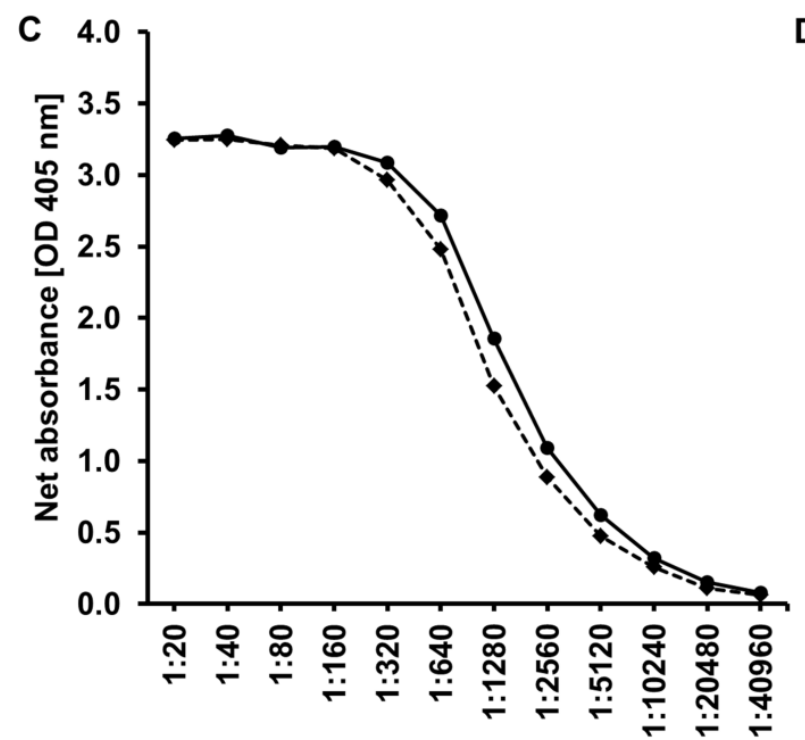

Patient 3 serum dilutions [titer]

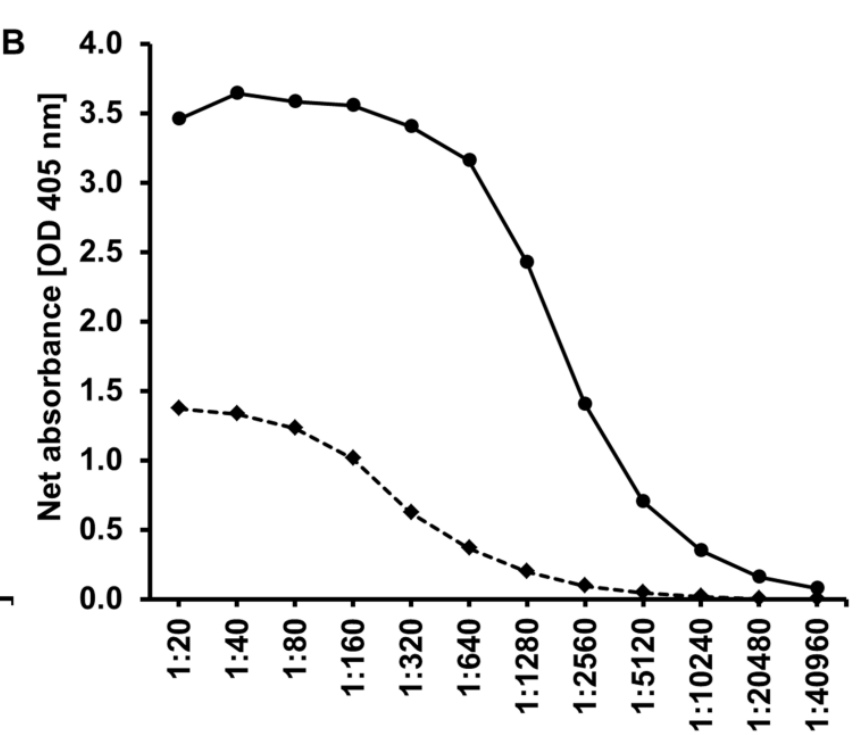

Patient 2 serum dilutions [titer]

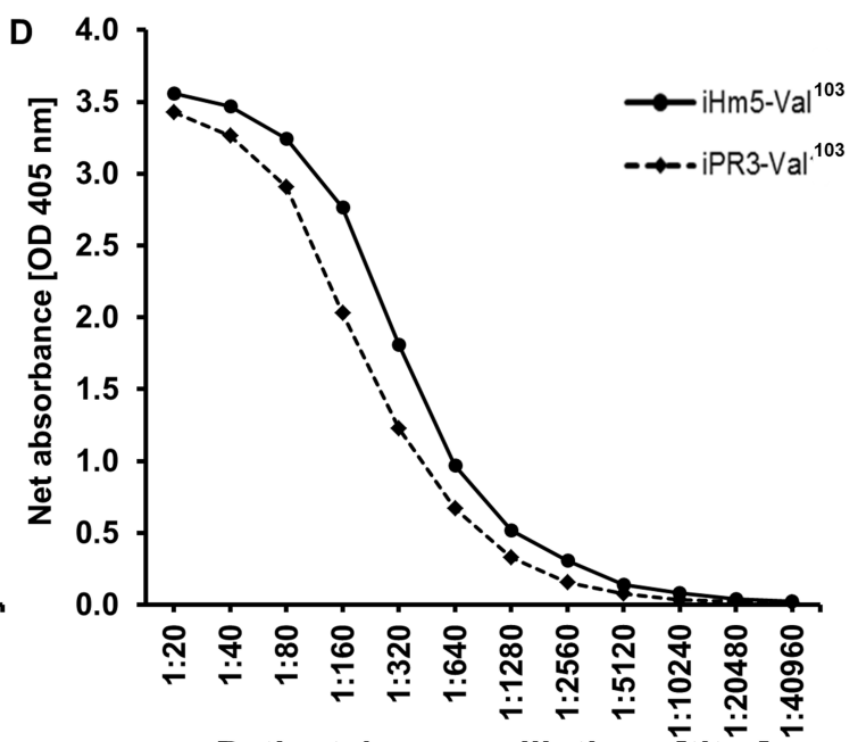

Patient 4 serum dilutions [titer] 
Figure 3

A

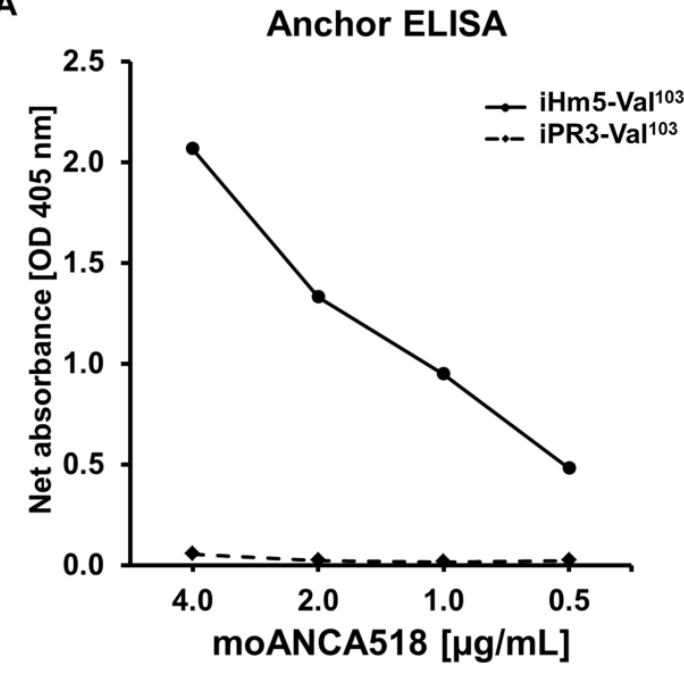

C

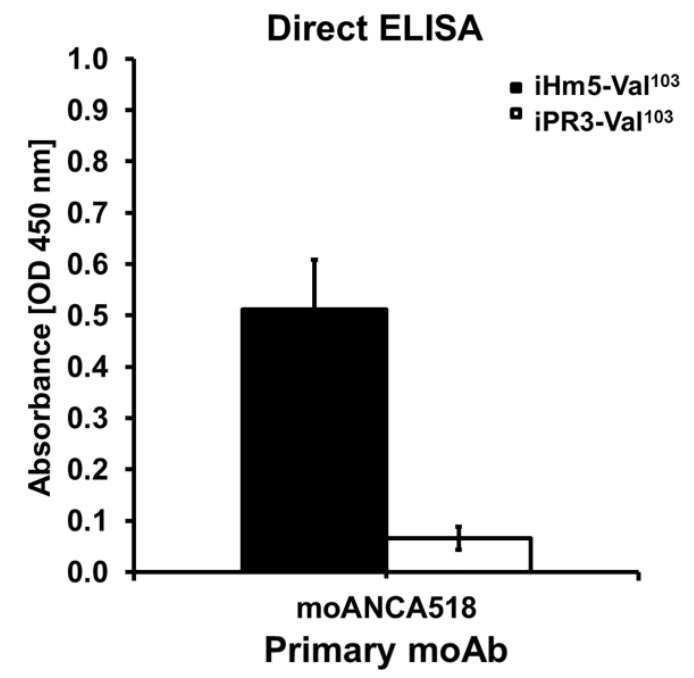

B

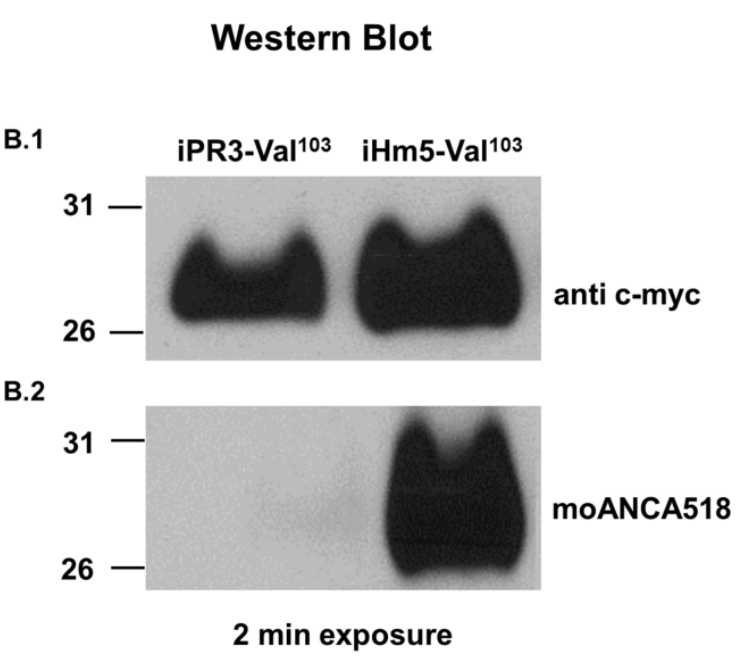

D

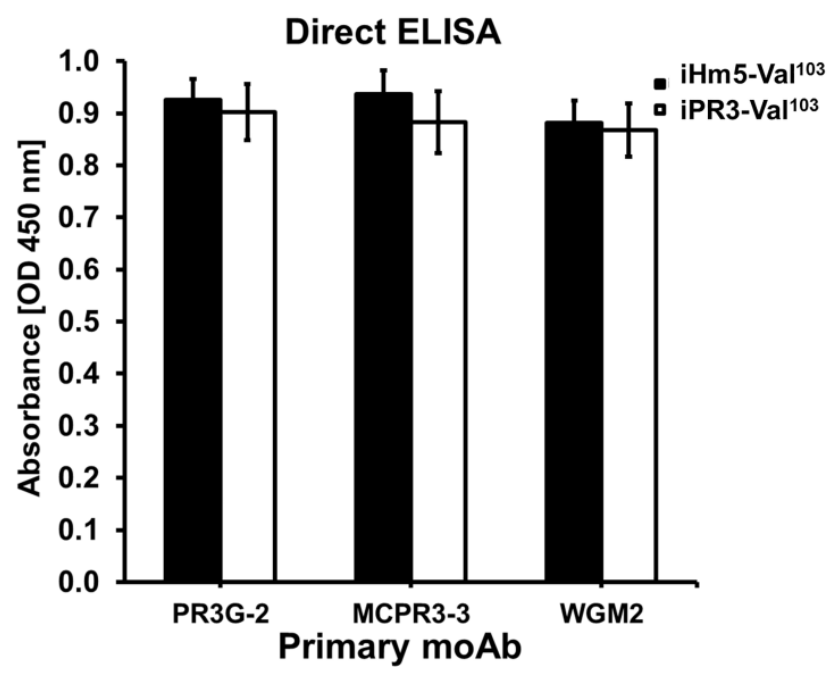


bioRxiv preprint doi: https://doi.org/10.1101/549063; this version posted February 14,2019 . The copyright holder for this preprint (which was not certified by peer review) is the author/funder, who has granted bioRxiv a license to display the preprint in perpetuity. It is made available under aCC-BY-NC-ND 4.0 International license.

Figure 4

A Binding of the moANCA518 to iHm5-Val ${ }^{103}$

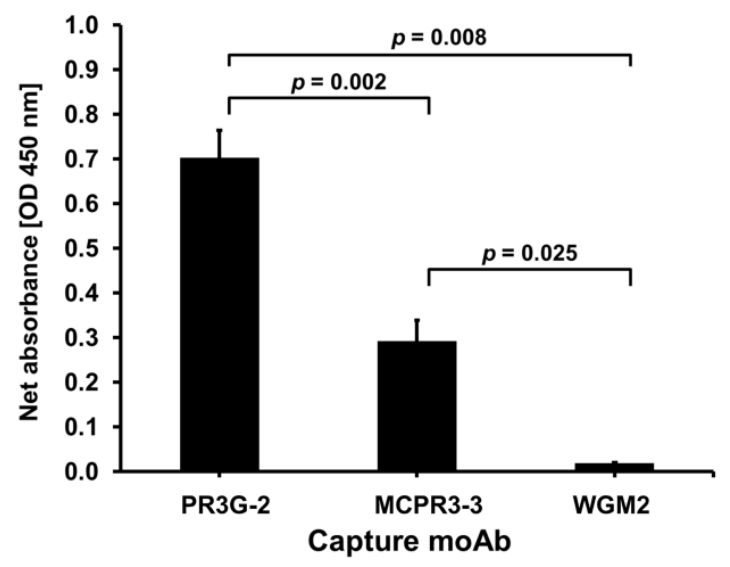

B Reactivity of PR3-ANCA serum with iHm5-Val ${ }^{103}$

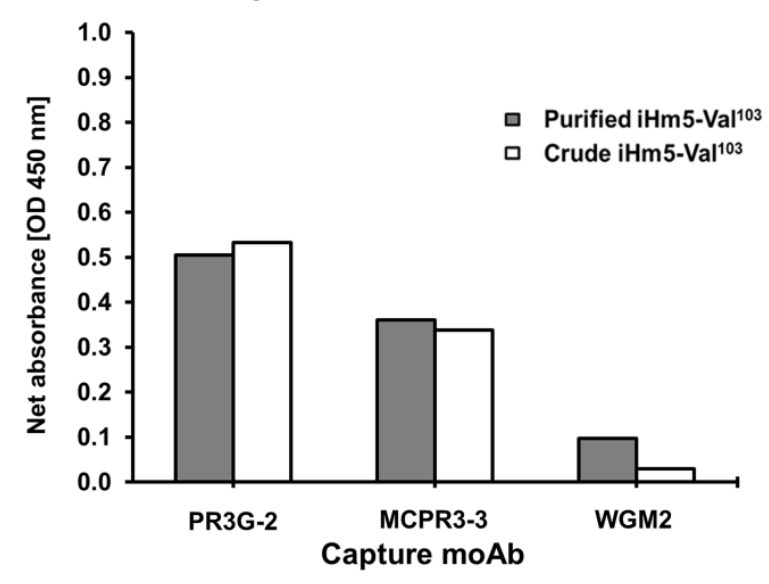


bioRxiv preprint doi: https://doi.org/10.1101/549063; this version posted February 14,2019 . The copyright holder for this preprint (which was not certified by peer review) is the author/funder, who has granted bioRxiv a license to display the preprint in perpetuity. It is made available under aCC-BY-NC-ND 4.0 International license.

Figure 5

A Inhibitor effect on moANCA518 binding to iHm5-Val'103

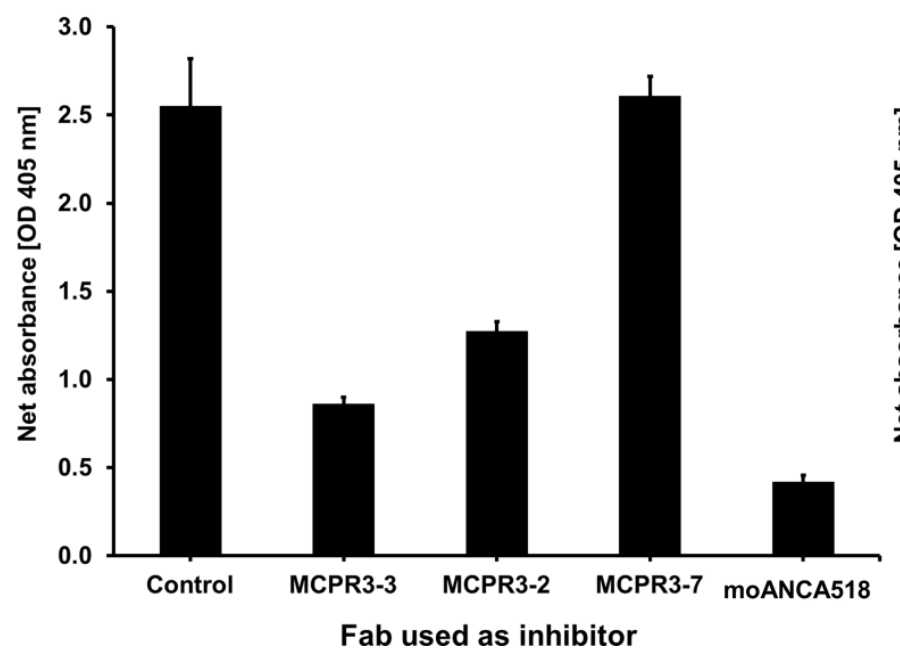

Fab used as inhibitor
B Inhibitor effect on PR3-ANCA plasma reactivity with iHm5-Val ${ }^{103}$

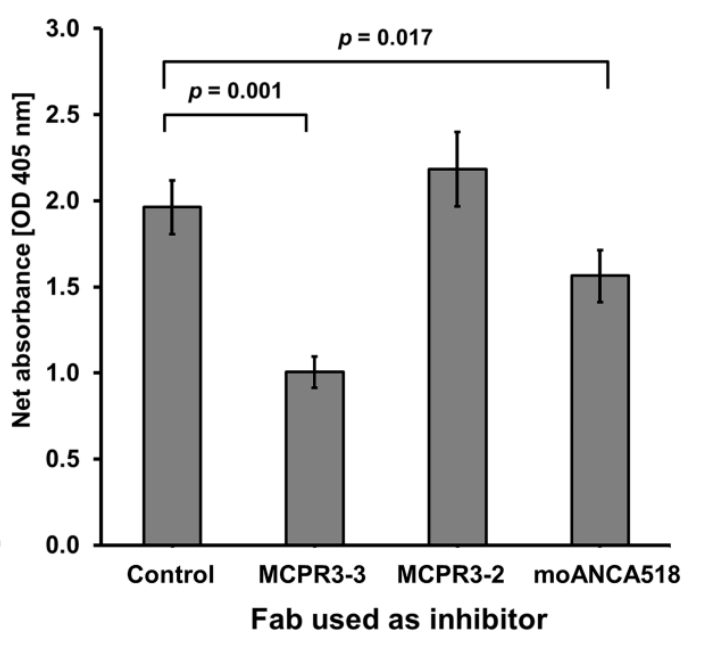




\section{Supplementary Figure}

A

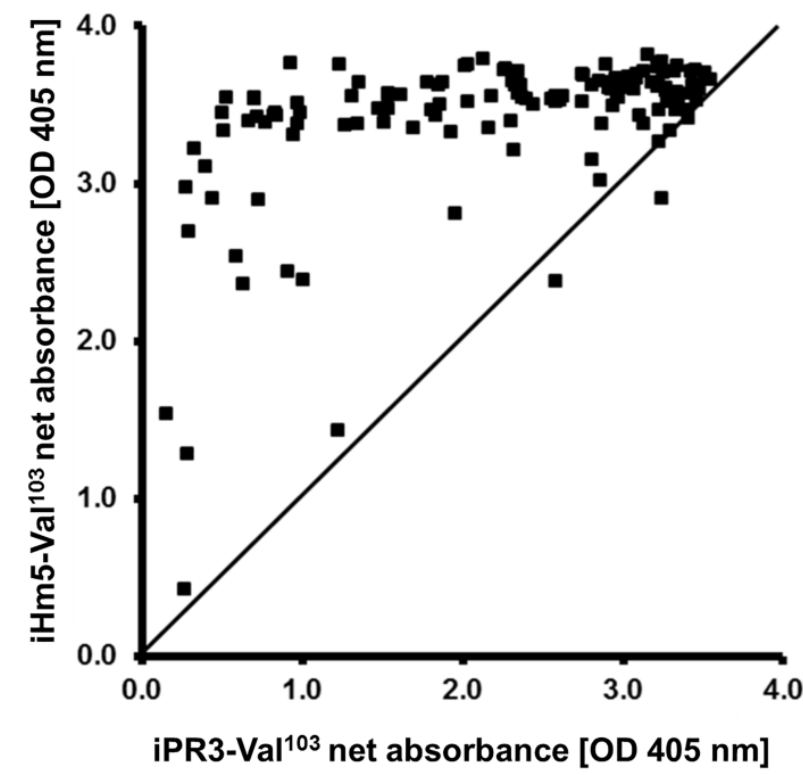

WGET
B

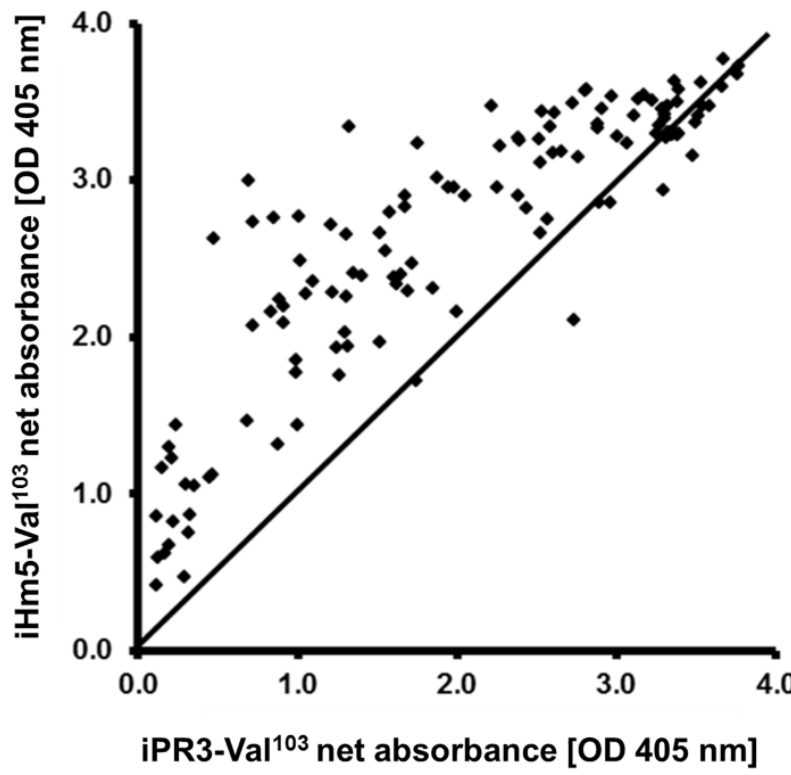


Table 1 - PR3-ANCA Reactivity with iHm5-Val ${ }^{103}$ and iPR3-Val ${ }^{103}$ by anchor ELISA

\begin{tabular}{|c|c|c|}
\hline \multicolumn{3}{|c|}{$\begin{array}{l}\text { The WGET study } \\
148 \text { PR3-ANCA positive samples* }\end{array}$} \\
\hline \multicolumn{2}{|c|}{ iHm5-Val ${ }^{103}$ positive } & iPR3-Val103 positive \\
\hline \multicolumn{2}{|c|}{$\mathrm{n}=144$} & $\mathrm{n}=135$ \\
\hline \multicolumn{3}{|c|}{ Comparison of net absorbance in 135 samples positive for both antigens } \\
\hline iHm5-Val ${ }^{103}>$ iPR3-Val ${ }^{103}$ & $\mathrm{iHm} 5-\left.\mathrm{Val}\right|^{103}=\mathrm{iPR}-\mathrm{Val}^{103}$ & iHm5-Val'103 $<$ iPR3-Val103 \\
\hline $\mathrm{n}=108$ & $n=26$ & $n=1$ \\
\hline $80 \%$ & $19 \%$ & $1 \%$ \\
\hline \multicolumn{3}{|c|}{$\begin{array}{l}\text { The RAVE study } \\
\text { 129 PR3-ANCA positive samples** } \\
\end{array}$} \\
\hline \multicolumn{2}{|c|}{$\begin{array}{l}\text { iHm5-Val }{ }^{103} \text { positive } \\
n=128\end{array}$} & $\begin{array}{c}\text { iPR3-Val }^{103} \text { positive } \\
n=126\end{array}$ \\
\hline \multicolumn{3}{|c|}{ Comparison of net absorbance in those positive for both antigens } \\
\hline iHm5-Val ${ }^{103}>$ iPR3-Val ${ }^{103}$ & $\mathrm{iHm} 5-\left.\mathrm{Val}\right|^{103}=\mathrm{iPR}-\mathrm{Val}^{103}$ & iHm5-Val ${ }^{103}<$ iPR3-Val ${ }^{103}$ \\
\hline $\mathrm{n}=89$ & $\mathrm{n}=34$ & $\mathrm{n}=3$ \\
\hline $71 \%$ & $27 \%$ & $2 \%$ \\
\hline
\end{tabular}

* positive for PR3-ANCA in at least one antigen-specific immunoassay (Finkielman et al. Am. J. Med. 2007); * positive for PR3-ANCA in at least one antigen-specific immunoassay (Fussner et al. Arthritis Rheumatol. 2016) 